19 Revue d'histoire du XIXe siècle

Société d'histoire de la révolution de 1848 et des

révolutions du XIXe siècle

13 | 1996

(Re)penser le XIXe siècle

Le XIXe siècle au miroir de la sociologie historique

Yves Déloy and Olivier IhI

URL: http://journals.openedition.org/rh19/97

DOI: $10.4000 /$ rh 19.97

ISSN: $1777-5329$

Publisher

La Société de 1848

Printed version

Date of publication: 1 December 1996

ISSN: 1265-1354

Electronic reference

Yves Déloy and Olivier Ihl, « Le XIXe siècle au miroir de la sociologie historique », Revue d'histoire du XIXe siècle [Online], 13 | 1996, Online since 10 September 2008, connection on 03 May 2019. URL: http://journals.openedition.org/rh19/97 ; DOI : 10.4000/rh19.97

This text was automatically generated on 3 May 2019.

Tous droits réservés 


\section{Le XIXe siècle au miroir de la sociologie historique}

Yves Déloy and Olivier IhI

\section{ABSTRACTS}

No abstract available by now

Pas de résumé disponible actuellement

INDEX

Mots-clés: Penser le dix-neuvième siècle 